\title{
Intra-Asian Infrastructures of Chinese Birth Tourism: Agencies' Operations in China
} and Taiwan ${ }^{\mathrm{a}}$

\section{Sean H. Wang}

Birth tourism describes the practice where pregnant women travel abroad to give birth.

Globally, the ethnic Chinese have been one of the most visible groups practicing birth tourism, but scholars know comparatively little about this unique practice. This chapter argues that commercialisation is the defining characteristic of Chinese birth tourism today and explores this process through a detailed, comparative examination of birth tourism agencies' operations in China and Taiwan. Agencies in China have developed an economy of scale and, together with maternity hotels in the US, form a tightly linked industrial chain; while agencies in Taiwan, operating at a smaller scale and following a 'DIY' ethos, pursue boutique strategies that target a well-educated clientele. These differences reflect existing intra-Asian geo-political and -economic linkages and demonstrate the increasing importance of agencies and other intermediaries in shaping specific new Chinese migration flows today.

Sean H. Wang is a Project Manager at the Max Planck Institute for the History of Science and a PhD Candidate in Geography at the Maxwell School of Syracuse University. His research interests include citizenship, family, feminist and ethnic studies.

\footnotetext{
${ }^{\text {a }}$ To cite: Wang, S.H. 2018. "Intra-Asian infrastructures of Chinese birth tourism: Agencies' operations in China and Taiwan." In Y.W. Chan and S.Y. Koh (eds.), New Chinese Migrations: Mobility, Home, and Inspirations (London, Routledge), pp. 112-127.
} 


\section{Intra-Asian infrastructures of Chinese birth tourism: Agencies' operations in China and Taiwan ${ }^{1}$}

Sean H. Wang

\section{Introduction}

Birth tourism describes the practice where pregnant women travel abroad to give birth. Although motivations behind it vary, many point to the lure of foreign citizenship for the newborns and, eventually, the entire family. In recent years, birth tourism has become visible in debates on citizenship and immigration globally (Wang, 2017, p. 265). In the US, a major birth tourism destination due to its jus soli birthright citizenship laws, what began as occasional local controversies in the late 2000s was thrust into the national spotlight during the most recent presidential campaign, when Republican candidates sparred over the derogatory term 'anchor babies' and its supposed Asian association (Davidson, 2015; Kessler, 2015). In the years leading up to this visibility (and continuing since), many US media have reported on these controversies, the majority of which have been located in southern California and featuring Chinese women (e.g. Carlson, 2015). Consequently, the ethnic Chinese have become one of the most visible groups practising birth tourism today.

Despite Chinese birth tourism's increased visibility, migration scholars know very little about it. Neither the prevalence nor the size of its practice is well established. There are few accounts of how an informal practice became an industry or of the geography of the transnational networks that sustain it. We know little about the familial outcomes of Chinese birth tourists and their US citizen-children or the political-economic conditions that motivate families in China to participate. Since starting preliminary fieldwork in southern California in March 2014, I have been conducting a multi-sited research project into on Chinese birth tourism, and this chapter is the first academic publication on the empirics of Chinese birth 
tourism to the US. Specifically, this chapter focuses on the development of a Chinese birth tourism industry and its intra-Asian operations (i.e., those components outside the US).

Besides space constraints, there are two primary reasons for this circumscribed scope of this chapter. The first has to do with US-based, English-language media's uneven coverage of Chinese birth tourism. As I have written about elsewhere (Wang, 2017), these reports had created a dominant narrative of wealthy Chinese families who 'cheat' their way into the US. This narrative obscures both the diverse demographics and motivations among Chinese birth tourists and the uneven and ambivalent attitudes toward this practice among Chinese citizens (see also Wu, 2016). Furthermore, the outsized attention Chinese birth tourism has received in the US meant that while birth tourism is practiced by many other than the Chinese and with many destinations outside the US (e.g. Balta \& Altan-Olcay, 2016; Luibhéid, 2013, ch. 2; Trémon, 2017; Yam; 2016), we know comparatively much more about Chinese birth tourism operations in places like southern California than we do elsewhere. Focusing on birth tourism's intra-Asian infrastructures, then, creates a unique opportunity to approach a new type of Chinese migration from a Chinese perspective; said differently, it takes a postcolonial approach to an inherently transnational practice by focusing on its geographic origins rather than foregrounding its impacts elsewhere (Mains et al., 2013).

Relatedly, what distinguishes Chinese birth tourism to the US from other nationalities is its scale and visibility, and both characteristics are made possible by its degree of commercialisation. Since 2014, multiple raids on Chinese birth tourism operations in southern California largely targeted these large-scale commercial operations (Shyong, 2016). While it is difficult to ascertain the number of birth tourists to the US by countries of origin, the growth of Chinese birth tourism in places like southern California is undeniable. This commercialisation, as I will show later, was only made possible by existing intra-Asian birth 
tourism connections. Hence, investigating the development of the Chinese birth tourism industry — even in the US — requires a focus on its intra-Asian infrastructures.

For these reasons, this chapter reorients our perspective regarding Chinese birth tourism away from the US and focuses on existing regional linkages, such as long-standing but small-scale informal birth tourism from Taiwan and a brief surge of Chinese birth tourism to Hong Kong (HK) in the 2000s, that buttress China-US birth tourism networks. Following a brief history of ethnic Chinese birth tourism, I focus on birth tourism agencies' operations in China and Taiwan. The proliferation of these agencies demonstrates Chinese birth tourism's commercialisation, arguably its most distinguishing feature today. In doing so, this chapter joins recent efforts to open up the 'black box' of contemporary migrations by focusing on the increasing centrality of intermediaries (e.g. labour recruitment agencies, smugglers, and other 'migration brokers') in organizing 'forms of infrastructure that condition [migrants'] mobility' (Lindquist, Xiang, \& Yeoh, 2012, p. 7; see also Xiang \& Lindquist, 2014), especially in China, where both the People's Republic of China (PRC) government and those who wish to move increasingly depend on these intermediaries to facilitate and manage migrations (Xiang, 2012; 2013). Furthermore, research to date on birth tourism globally had largely focused on either the medical providers' perspective (e.g. Mikhael et al., 2016), the birth tourists' reflections on their motivations and experiences upon their return (e.g. Balta \& Altan-Olcay, 2016), or reception locales' responses to birth tourism (e.g. Yam, 2016). This chapter thus contributes to this emerging literature by providing empirics on Chinese birth tourism agencies' operations and, to a lesser extent, prospective birth tourists' experiences at these agencies.

\section{Histories of Chinese birth tourism}


The ethnic Chinese have been one of the most visible groups practicing birth tourism, and a transnational industry facilitating it to the US was well established by the early 2010 s. While its growth in places like southern California may appear rather sudden, given the number of birth tourism-related controversies since the late 2000 s, the practice has a long history prior to its current, highly commercialised form. This section provides brief historical overviews of two prior iterations of birth tourism that shaped the Chinese birth tourism industry today: (1) informal birth tourism (especially by the Taiwanese and other nationalities with access to the US) in the second half of the twentieth century and (2) the brief but comparatively voluminous wave of mainland Chinese birth tourism to HK in the 2000s.

Contrary to what its name implies, birth tourism likely did not begin as a 'tourist' activity (i.e., using tourist or other short-term visa to enter a foreign country with the express purpose to give birth). While some maternity hotel operators in southern California suggest that commercialised birth tourism operations existed as early as the 1960s for Koreans (and rumours of similar operations for the Turks on the East Coast of the US), ${ }^{2}$ practices of birth tourism began for the ethnic Chinese in a small-scale, chained-migration fashion in the 1970s. This early period of Chinese birth tourism, from the 1970 s to the 1990 s, was dominated by the Taiwanese and characterised by informal arrangements (rather than the commercialised form seen today). Like the overall ethnic Chinese diaspora to the US during the same period, Taiwanese (and, to a lesser extent, Hongkonger) migrants had a larger presence due to the large number of student-migrants from Taiwan who came to the US to pursue graduate education and the heavily restricted emigration flows by the communist PRC government (Pieke, 2007; Pieke \& Mallee, 1999). ${ }^{3}$ The majority of these Taiwanese studentmigrants were primarily young men with accompanying wives, and many had children while in the US. For those who settled in the US following completion of their study, birth tourism emerged as a long-term immigration strategy for their extended families for whom, given the 
quota in place for non-immediate relatives, family-sponsored immigration could have taken just as long. Furthermore, many of these extended family members never intended to immigrate permanently to the US, so birth tourism offered a strategy that maximized potential future benefits for their children, giving them educational access and protection from the political uncertainty and instability across the Taiwan Strait. Immigration decisions resulting from these deliberations have been well documented, especially for migrations from HK and Taiwan, and birth tourism was a less drastic and more affordable strategy than permanent relocation for many families (see Waters, 2003, p. 226; 2009).

I characterise these early, informal instances of birth tourism to the US as 'do-ityourself' (DIY) style. These trips were privately arranged through family and extended guanxi (關係) $)^{4}$ networks and thus, were only accessible to those with prior contacts with the US, either by themselves or through extended families. Even though Taiwanese citizens were not visa-exempt back then, a US tourist visa-once secured - was good for a six-month stay, providing ample time for delivery and recuperation. In southern California, cities like Monterey Park, dominated by waisheng (外省, 'outside the province': a term referring to those who came to Taiwan following the Chinese Civil War and their descendants) Taiwanese immigrants during that period, also provided a dense ethnic network that facilitated these informal endeavours (Fong, 1994). Although birth tourism during this early era had a different demographic and resulted in different practices, we can still observe its continuities to today's birth tourism industry.

Another precursor to today's Chinese birth tourism industry to the US is a brief but large stream of Chinese birth tourists to HK in the 2000s. Prior to HK's reunification with the PRC in 1997, the British and Chinese governments agreed to the Sino-British Joint Declaration in 1984, which laid out the basic principles of HK's handover from the British to the PRC and codified what is known today as the 'one country, two systems' principle. Under 
this agreement, the PRC agreed to preserve HK's autonomy for 50 years (until 2047) and that further details of HK's post-reunification governance during this 50 -year period would be stipulated in a constitution-like document, the Basic Law of the Hong Kong Special Administrative Region of the PRC.

The Basic Law had established basic criteria of establishing someone's 'right of abode' in HK, a legal status akin to HK citizenship, but these criteria were vague regarding the birthright transmission of this status. Between 1997 and 2002, a 'period of elaboration and consolidation of the regime of rights' in HK, these 'right of abode' criteria were sharpened and specified under intense public attention (Chen, 2011, p. 281). A series of court cases, a PRC interpretation of the Basic Law, and even more subsequent court cases essentially put in place a curtailed jus sanguinis principle for children born to HK permanent residents outside HK (Fokstuen, 2003; Ku, 2001). Another 2001 case, Director of Immigration v. Chong Fung Yuen, established jus soli principle regardless of parents' right of abode status in HK. This was significant as HK's Court of Final Appeal ruled on three cases regarding right of abode in 2001, and the Chong decision was the only one that opened up (rather than further restricting) criteria for acquiring the right of abode (Fokstuen, 2003). HK government, generally siding with their Beijing superiors, actually went on record with its disappointment with the Chong decision (People's Daily, 2001). Many Hongkongers, however, were ambivalent toward the Chong decision: while it demonstrated HK's supposed judicial independence from the PRC, it also created additional migration streams into $\mathrm{HK}$ for Mainlanders (Apple Daily, 2011; cf. people, 2010).

These complex right of abode decisions in HK resulted in many cross-border and/or mixed-status families (So, 2003; Yuen, 2011). In 2001, the year of the Chong decision, 620 out of 48,219 live births (1.29 percent) in HK were born to mainland Chinese women without a HK resident spouse; by 2012, figures for these 'double-non' babies had risen to 26,715 out 
of 91,343 total live births (29.25 percent) (Department of Justice, 2013, Annex A). As HKChina relations worsened in the 2000s, public opinions turned sour toward Mainland Chinese migrants, especially these women and the intermediaries who help facilitate their arrivals in HK (Rowen, 2016; Yam, 2016). Facing public pressure, the HK government implemented a 'zero-quota' policy in 2013, prohibiting delivery bookings by Mainland Chinese women in HK public hospitals and denying entry to those pregnant and without prior travel approval. It also stepped up prosecutorial efforts against Mainland Chinese women who overstayed their visas and so-called 'gate-crashers' who showed up to emergency rooms ready to deliver (Tsang, 2016), while also co-operating with Guangdong provincial authorities in China to arrest and jail intermediaries (such as birth tourism agents and cross-border van drivers) (Food and Health Bureau, 2013).

A full account and analysis of Chinese birth tourism to HK between 2001 and 2013 is beyond the scope of this chapter, but suffice to say, this episode in HK demonstrates the increasing importance of migration intermediaries in shaping birth tourism flows from the 2000s onward. Furthermore, while birth tourism from China to the US had been gaining steam over the same period, birth tourism agencies in China were responding to changing birthright citizenship policies globally. Besides HK, the same period saw reports of Chinese birth tourism in the European Union and Canada as well (Bewley et al., 2014; Wong, 2014). Most relevantly, the dramatic growth of Chinese birth tourism to the US could be attributed in part to the halt of flows, especially from Guangdong and other south-eastern Chinese provinces, to HK following 2013 (people, 2014). As multiple birth tourism agency representatives told me, HK was a particularly attractive destination for many in the region because it speaks Cantonese and is still considered a Chinese territory (see also Cheng, 2016; Yam, 2011). However, political uncertainties regarding HK's future after 2047 and the 'zero- 
quota' policy put an end to much of this regional birth tourism flows and redirected it elsewhere. $^{5}$

\section{Infrastructures of the Chinese birth tourism industry}

As the brief history above demonstrates, current birth tourism operations trace their lineage to previous networks and geographies. But the increasing frequency of Chinese birth tourism controversies in southern California since the late 2000s also shows that what we are seeing today is a different beast; birth tourism to the US from Mainland China had been gaining steam since HK's ban in 2013, and crackdowns by US authorities in 2015 and 2016 only slowed it somewhat. ${ }^{6}$ The increasing speed and scale of Chinese birth tourism are attributed in large part to its commercialisation. The numbers of early Taiwanese 'DIY'-style birth tourists are dwarfed by Mainland Chinese women who use birth tourism agencies to arrange for maternity hotels, as well as for medical care, delivery, and post-partum care abroad. The proliferation of agencies that arrange and provide these services means that we can now speak of a transnational Chinese birth tourism industry that facilitates the majority of trips by these Chinese women. The rest of this chapter focuses on intra-Asian infrastructures of contemporary Chinese birth tourism industry, describing separately for birth agencies in China and Taiwan their (1) modes of recruitment, (2) clientele demographics, and (3) scales of operations. I then use these empirics to discuss how contemporary birth tourism operations have developed from those early incarnations and implications for studying new Chinese migrations.

\section{Chinese birth tourism agencies in Guangzhou: 'industrial chain'}

In November 2015, I went to Guangzhou to visit nine birth tourism agencies based there. I identified these agencies from word-of-mouth referrals from my fieldwork in southern 
California (March 2014; June-July 2015), online research (especially on Chinese social media sites like Weibo, WeChat, and various Chinese parenting blogs), and Chinese-language media reports on birth tourism. Based on their websites, four are national agencies with regional offices in Guangzhou, three are subsidiary units of larger immigration agencies, and the remaining two are independent agencies. Following initial visits, I returned to Guangzhou in February-March 2016 for further research. Besides Guangzhou's prominence as a sending region of birth tourists, its proximity to $\mathrm{HK}$ (and, to a lesser extent, Taiwan) meant that I was able to tease out contemporary Chinese birth tourism's link with its historical precursors. Furthermore, I had planned to visit the trade association of Chinese birth tourism agencies, purportedly based in Guangzhou, that had produced a white paper on the state of the industry in 2014 , though I was unable to track down this organization. In fact, only two agencies' employees I spoke to in Guangzhou were aware of this white paper. ${ }^{7}$ These inconsistencies between the industry's online presence and reality on the ground turned out to be a key characteristic of its modes of recruitment.

Of the nine agencies I identified, all but one have glossy, well-designed websites, complete with articles touting birth tourism's benefits and many different ways of contracting services that do not require an in-person visit (e.g. through live chats online, WeChat messaging, and - for two agencies - in-home visits by agency representatives). The virtual recruitment of clientele is especially important for national agencies that have achieved a certain economy of scale in their operations. As one such agency's Guangzhou office manager told me,

While we'd like to meet each potential client in person, this is in fact unnecessary. China is simply too big of a country for that business strategy to be realistic. Yes, having [clients] in our offices makes it easier for us to show the whole range of services we can 
provide, but we won't turn away families who contact us some other way. I mean, everybody can easily book flights and hotels online now; that's like a quarter of steps accomplished already. ${ }^{8}$

This perspective underlies the centrality of the Internet in birth tourism operations today; besides agencies, social media and blogging have also made it easier for (prospective) birth tourists to share their experiences and seek advice from others. The proliferation of these online spaces has helped enable new modes of interaction in diasporas (Hiller \& Franz 2004), diffuse imaginative geographies that influence migratory decisions (Vilhelmson \& Thulin, 2013), and expand migration industries globally (Gammeltoft-Hansen \& Sørensen, 2013). However, such virtual spaces also increase the risk of deception by unscrupulous intermediaries (Fernandez, 2013; McKeown, 2012). Indeed, this issue persists in the Chinese birth tourism industry. Two out of the nine agencies I identified were not at their stated addresses, and further outreach received no reply. Stories of agencies who misrepresented their services or took advantage of their clients' lack of English abound as well (Berfield, 2015; Kopetman, Puente, \& Schwebke, 2015).

Given the supposed rapid growth of the Chinese birth tourism industry, just exactly how big is it now? This proved difficult to answer. Many reports characterise it as a 'grey' industry, as neither the PRC nor the US government has any official policies regulating these agencies' operations (Meacham, 2016; people, 2013; 2014). It also hinges on whether one counts the number of birth tourism agencies in China, the total number of their clients, or the total number of Chinese birth tourists (which includes those who practice 'DIY'-style), and none of the above has a conclusive number. A 2014 report by the Chinese news site people had this quote from an anonymous industry insider:

I estimate that only a few [birth tourism] agencies have more than one to two hundred employees nationally. The number of agencies 
with 10 to 20 employees is probably in tens. Of course, the kind of "guerrilla operations" with two or three employees in a small rented office are numerous (people, 2014).

These small-sized 'guerrilla operations' are only possible given the Internet and other communicative technologies. The same report includes the following figures for the number of Chinese women who went the US to give birth: $\sim 600$ in 2007, 5,000 in 2010, and more than 10,000 in 2012. A white paper predicted that those figures would rise to 60,000 by 2015 , though crackdowns on and protests against maternity hotels in southern California in the past four years likely slowed the growth (A-AMSM, 2014). Another detailed report by $q q$, a large Chinese social media and news network site, in 2015 did not include revised estimates but concurred with previous reports that Chinese birth tourists are largely middle- to upper-class residents in their 30s from large cities and/or coastal provinces, with those from Guangdong province accounting for the largest share (about 15 percent) (qq.com, 2015). These inconclusive figures aside, what is more indicative of this industry's growth is in the nomenclature. The aforementioned white paper asserts that it is now entirely reasonable to speak of birth tourism as an 'industrial chain' (A-AMSM, 2014, p. 6), with healthy cash turnover and diverse agents that span the Pacific (see also sina, 2010). Even with a more conservative estimate, the Chinese birth tourism industry as a whole likely brought in US\$150,000,000 worth of revenue in 2012. Although employees at birth tourism agencies in Guangzhou were understandably tight-lipped when I inquired about their scales of operations (especially financial details), they had no problem admitting that it is a lucrative business, and their settings reflect as much; one agency had recently relocated to a brand-new, 100-story skyscraper in central Guangzhou, and automatic document scanners lined the lobby for visitors to obtain temporary entry passes. 
It is apt to conceptualise contemporary Chinese birth tourism as an 'industrial chain'. It highlights two intertwining characteristics of this industry's commercialisation: its reliance on established 'migration chains' (Johnston et al, 2006) and its development as an 'ethnic industry' (Fong \& Shen, 2011). Both reflect dense networks of knowledge and relationships along established ethnic Chinese migratory pathways, which the practical steps of birth tourism also follow. An expectant Chinese mother who use an agency to arrange for birth tourism to the US would go through the following steps. After signing a contract with an agency, the mother must secure a US tourist visa (and Chinese exit permits if necessary), before traveling to the US. After settling in at her accommodation, she must secure a physician for check-ups and delivery. Following successful delivery, she must apply for a birth certificate and a US passport for her baby, before traveling back to China. She also must decide, prior to returning, whether to bring the child into China as a foreigner or apply for Chinese citizenship at the local Chinese consulate. This decision would have additional implications for the child's hukou (户口, household registration) status and public education opportunities, as well as the potential choice between Chinese and US citizenships once the child became of age (the PRC prohibits dual citizenship for adults). Each step along this entire process involves different intermediaries and institutions.

Birth tourism agencies in China are primarily involved in recruitment by packaging services offered by downstream providers (e.g. maternity hotels in the US). Put simply, they are migration intermediaries in the truest sense: they advise their clients on visa applications and border crossing strategies and sell pre-packaged accommodations and services with contracted maternity hotels in the US. Only the largest few agencies actually own and operate maternity hotels in the US. The great majority work with maternity hotel operators and take a percentage for any bookings. Pricing for different packages depends on the types of accommodation and services included. The all-inclusive option covers the entire process, 
from securing documents and making travel arrangements to room and board in the US and medical care and post-partum confinement rituals. These could cost up to US $\$ 45,000$, depending on the length of stay in the US and payment arrangements with delivering physicians and the yuesao (月舅, specialty maid who takes care of the mother and baby after delivery). The most basic package resembles the 'DIY'-style, with basic accommodation in the US and referrals for other services (costs not included). Another arrangement, more common in Mainland China than Taiwan, involves large maternity hotel operators cutting out the middlemen and recruiting directly in China. As one agency employee told me,

Now that [the industry] has achieved a certain economy of scale, diversifying is the name of the game. We're seeing a more diverse set of parents who seek out our services, so we want to give them the best choice to suit their families. If you're a haigui (海龟, 'sea turtle'; a Chinese slang for 'return migrants') who just wants a quiet apartment with a cook during your pregnancy, we can do that. If you're a tuhao (土豪, a derogatory term for the nouveau riche in China) who doesn't speak a word of English and wants everything arranged and pre-paid, we can do that too. We have many partners in southern California and we can tailor everything to a client's

$$
\text { needs. }{ }^{9}
$$

Indeed, agency advertising materials and brochures reflect this trend of flexibility, with as many as seven types of accommodations offered in the US and prices for add-on services. But this flexibility also sometimes led to the lack of on-site oversight and customer complaints, including aforementioned allegations of fraud. Nonetheless, this diversity of options is only made possible by the scale of the industry. 


\section{Birth tourism agencies in Taiwan: 'boutique industry'}

While birth tourism from Taiwan began in an informal, 'DIY' fashion, it also has been commercialised in recent years. Many Chinese agencies point to the Taiwanese as the 'pioneers' in this regard. ${ }^{10}$ Despite its longer history, Taiwanese birth tourism industry now pales in comparison with its Chinese counterparts in both size and degree of commercialisation. With this historical legacy, it is unsurprising that agencies in the two countries share a number of features. With its smaller size and 'DIY' tradition, Taiwanese agencies have carved out a niche for those with a Western education (but not necessarily wealth). Its presence in southern California reflects this characterisation too, as Taiwaneseoperated maternity hotels tend to be much smaller and discreet. To investigate Taiwanese birth tourism agencies, I spent time in Taipei during September-November 2015 and AprilMay 2016, attending a number of information and recruitment sessions hosted by different agencies and meeting with their representatives and prospective birth tourists there.

While the process of birth tourism remains largely the same for Taiwanese agencies, their 'DIY' legacy is immediately recognizable. Taiwan has a culture of emigration (e.g. Faist, 2000), and its geography, history of colonisation, and especially density meant that knowledge of emigration is more widely prevalent among its population than in China (Roy, 2003; Shih, 2007). These international connections, especially with the US during the twentieth century prior to the PRC's opening, made 'migration aspirations' (Carling, 2014) an integral feature of Taiwanese cultural politics. This general familiarity with the US is reflected in the demographics of Taiwanese birth tourism clientele. As one agency representative told me, 'The majority of our clients have been to the US in the past and speak enough English to get by, so that has a definite impact on how we design our packages and what services we focus on'. ${ }^{11}$ 
Geopolitical positioning vis-à-vis the US directly impacts Taiwanese birth tourism industry as well. Since 2012, Taiwan has been a participating country in the US's Visa Waiver Program (VWP). As a result, eligible Taiwanese citizens only need to register online and pay a small fee (currently US\$14) before they are authorized to travel to the US for up to 90 days without a visa (Siskin, 2011). The VWP designation had been one of Taiwan's key foreign policy objectives for years and was accomplished after intense diplomatic lobbying (Kan \& Morrison, 2013). With this designation, Taiwan joins a select group of only 38 countries worldwide whose citizenry are deemed by the US to be sufficiently low-risk for visa-free travel.

While Taiwan's VWP participation raises a number of theoretical implications (see Mau, 2010), it produced two practical outcomes for the Taiwanese birth tourism industry. First, since Taiwanese citizens do not require a visa to travel to the US, it eliminates much of the pre-departure portfolio for the birth tourism agencies. This is undoubtedly seen as a positive development by both agencies and prospective birth tourists. The second outcome is not so positive, however. A standard tourist visa to the US allows for a stay up to six months, but travellers with VWP only get 90 days (without the possibility of extension or status adjustment). This meant that Taiwanese birth tourists have to travel to the US at a later stage of pregnancy to ensure sufficient time for delivery and the receipt of baby's birth certificate and US passport, all within 90 days, lest they risk either not delivering in time or having to leave the baby behind in the US while her US passport application is in process. This could lead to risky behaviours that are potentially damaging to the expectant mother's health (e.g. flying during late-term pregnancy; Lind, 2015). It also shifts the geographies of birth tourism within the US. At one information session, a birth tourism agency owner spoke about severing its partnership with maternity hotels in the Bay Area and focusing exclusively on southern California because certain northern California counties take longer to file birth 
certificates, making it difficult to fit everything within the 90-day timeframe. ${ }^{12}$ Standard packages offered by Taiwanese agencies now are only 60 days, a month before delivery and another month after for post-partum confinement, while it is not uncommon for Mainland Chinese women to book for 4-5 months. These cultural and geopolitical features specific to Taiwan resulted in, overall, a greater awareness of birth tourism among the population, and the VWP designation had made birth tourism to the US much easier, despite these potential complications.

Taiwan's 'DIY' legacy translates into specific characteristics. Compared to those in China, agency operators in Taiwan are much more open about the specifics of the birth tourism process and recognize that in addition to competing against one another, a number of their prospective clients end up going it alone. This tendency is exacerbated by Taiwanese birth tourism industry's combination of many small-scale operations in a highly fragmented landscape — what I would characterise as a 'boutique industry'. First, in terms of its organization, the kind of larger-scale, transnational operations that we sometimes see in China, where a single company operates both agencies at home and maternity hotels in the US, is virtually unheard of in Taiwan. While Taiwanese agencies usually have formal cooperative relationships with (Taiwanese) maternity hotels in southern California, it is also common to see families booking directly with a maternity hotel. In this sense, the Taiwanese 'industrial chain' is a looser one, composed of multiple independent but interlocking components rather than the one more closely resembling complete vertical integration in China.

Second, birth tourism in Taiwan is much more targeted in its marketing. While agencies in China pride themselves on 'serving all comers (as long as they can pay)', Taiwanese agencies are generally smaller operations with specialisations. Said more simply, while birth tourism is primarily a wealth marker in China, it is much more of a (social) class 
marker in Taiwan. Information on birth tourism is widely available online, especially in many well-publicised 'mommy blogs', and VWP took away the biggest hurdle to birth tourism: visa interviews with US consular officers. With the older Taiwanese social networks in southern California, for a Taiwanese couple who speak English and have friends or families in the US, the price of birth tourism could be flight tickets, medical bills (subject to partial reimbursement upon return, thanks to Taiwan's universal healthcare), and two-plus months of their (or her) time. As one Taiwanese agency owner (who did it 'DIY'-style herself in the early 2000s) readily admits, 'It's a tough business because [birth tourism to the US] is just too easy for us Taiwanese! Even if you don't know anything about it, you could come to my information session and just follow what I tell you step-by-step yourself'. ${ }^{13}$ And I can vouch for her. While Chinese agencies trade in glossy brochures and vague descriptions prior to signing the contract, Taiwanese agencies are detailed and specific from the get-go because they know they do not have a monopoly on the 'how-to' of birth tourism. In the most extreme case, at one information session (free registration open to the public), every attendee received a gift bag containing an American flag pin, a bag of Chinese medicine used for bathing during post-partum confinement, and a thick binder of information detailed to the point that I could run a birth tourism consultancy based on that if I wanted to!

Under these conditions, Taiwanese agencies had to pursue certain 'boutique' strategies, such as one-on-one client advising throughout the entire process, including administrative tasks post-delivery and return to Taiwan. In terms of day-to-day operations, this is perhaps the most significant difference between Taiwanese and Chinese agencies. Many Taiwanese agencies include in their packages administrative tasks both in the US (like US passport application, Taiwanese visa or passport application, depending on whether the parents plan to pursue dual citizenship for the newborn or Taiwanese permanent residency as a foreigner) and in Taiwan (like hukou registration, universal health insurance registration, 
and mandatory child vaccinations). While some Chinese agencies do provide similar services, it is not nearly as comprehensive and never included as part of the package free-of-charge. One Taiwanese agency owner proudly boasted, 'This is what sets our services apart. We are with our parents all the way, working with them even after they've returned [from the US]. This is how we compete in the industry'. ${ }^{14}$ Notably, some agencies offer these post-delivery administrative services à la carte for 'DIY' birth tourists as well. This boutique strategy reflects not only differences in scale between Taiwanese and Chinese birth tourism industries but also different (dual) citizenship policies and geopolitical positions vis-à-vis the US.

\section{Discussion and conclusion}

As the empirical data presented in this chapter demonstrate, contemporary ethnic Chinese birth tourism to the US is overwhelmingly commercialised and draws its clientele from both sides of the Taiwan Strait. While controversies involving Mainland Chinese birth tourists in southern California since the late 2000s thrust this practice into US public consciousness, ethnic Chinese birth tourism has a longer history, which continues to inform current practices and attitudes. Studying agencies' operations in China and Taiwan reveals birth tourism as a dynamic process: alongside aforementioned continuities, geo-political and -economic changes both within the region and vis-à-vis the US forced the industry to respond and adapt in recent years, shifting its geographies during a period of expansion. Birth tourism agencies' centrality to this development echoes recent arguments about the increasing role of intermediaries and brokers in shaping global migration flows, especially from the AsiaPacific (Lindquist et al., 2012). In this regard, we can understand birth tourism as a type of 'new' Chinese migration even though, of course, it is not really new.

In addition to these large-scale implications, focusing on birth tourism's intra-Asian infrastructures also opens fruitful avenues for future research. This chapter sidesteps 
dominant transnational narratives of Chinese birth tourism that primarily focus on linkages between migratory origins (i.e., China) and destinations (i.e., the US). Instead, the expansion of Chinese birth tourism to the US demonstrates how commercialised values of US citizenship not only spurred new China-US relations but also re-shaped intra-Asian linkages and relations. Both the histories of birth tourism and the comparison between Chinese and Taiwanese birth tourism industries reflect this point. A 2010 report estimated the makeup of ethnic Chinese birth tourists to southern California as 65 percent Mainland Chinese, 30 percent Taiwanese, and 5 percent Hongkonger (with the caveat that the proportion of Mainland Chinese likely have increased significantly since then) (sina, 2010). The shared ethnic identity and (sometimes) spoken language among these groups make it easy to paint them with broad strokes. Yet, this chapter has shown there to be significant differences and interactions among them, which directly impact how birth tourism is practiced. Practices of birth tourism thus draw from, reinforce, and reconfigure existing ideas about citizenship, economic development, national identity, and urban environment across multiple ethnic Chinese communities. Although all place additional value on a foreign (i.e., US) citizenship, a comparative approach toward birth tourism agencies' operations in China and Taiwan reflects a new commitment to studying 'Chinese' migration while being sensitive to its heterogeneity.

\section{References}

A-AMSM (2014, September 23). 全美月子中心产业白皮书 (All-America Postpartum Care Centre Industry White Paper). Retrieved 31 May, 2017 from http://www.aamsm.com/news_detail.php?n_id=388

Apple Daily (2011, May 1). 攻破居港權第一人, 引發來港產子潮 莊豐源 : 我不是蝗蟲

(The first to break through Hong Kong right of abode, causing waves of [Mainland] 
births in Hong Kong; Chong Fung Yuen: 'I am not a locust'). Retrieved 31 May, 2017 from http://hk.apple.nextmedia.com/news/art/20110501/15214738

Balta, E. \& Altan-Olcay, O. (2016). Strategic citizens of America: Transnational inequalities and transformation of citizenship. Ethnic and Racial Studies, 39(6), 939-957.

Berfield, S. (2015, May 13). Chinese maternity tourists and the business of being born American. Bloomberg. Retrieved 31 May, 2017 from https:/www.bloomberg.com/news/articles/2015-05-13/chinese-maternity-touristsand-the-business-of-being-born-american

Bewley, S., Bragg, R., Popay, S., \& Fitzgibbon, A. (2014). Immigration and pregnancy in the UK. The Lancet, 383(9912), 123-124.

Carling, J. (2014). The role of aspirations in migration. PRIO Working Papers. Oslo: Peace Research Institute Oslo.

Carlson, B. (2015, August 19). Welcome to maternity hotel California. Rolling Stone. Retrieved 31 May, 2017 from http://www.rollingstone.com/politics/news/welcome-tomaternity-hotel-california-20150819

Chen, A. H. Y. (2011). The rule of law under 'one country, two systems': The case of Hong Kong 1997-2010. National Taiwan University Law Review, 6(1), 269-299.

Cheng, K. M. (2016). Medical tourism: Chinese maternity tourism to Hong Kong. Current Issues in Tourism, 19(14), 1479-1486.

Davidson, A. (2015, September 15). The anchor-baby question at the G.O.P. debate. The New Yorker. Retrieved 31 May, 2017 from http://www.newyorker.com/news/amydavidson/the-anchor-baby-question-at-the-g-o-p-debate

Department of Justice, Hong Kong (2013, May 28). Right of abode issues of children born in Hong Kong to Mainland parents both of whom are not Hong Kong permanent residents. Hong Kong: LegCo Panel on Administration of Justice and Legal Services. 
Retrieved 31 May, 2017 from

http://www.doj.gov.hk/eng/public/pdf/2013/ajls0528e.pdf

Faist, T. (2000). Transnationalization in international migration: Implications for the study of citizenship and culture. Ethnic and Racial Studies, 23(2), 189-222.

Fernandez, B. (2013). Traffickers, brokers, employment agents, and social networks: The regulation of intermediaries in the migration of Ethiopian domestic workers to the Middle East. International Migration Review, 47(4), 814-843.

Fokstuen, A. R. (2003). The 'right of abode' cases: Hong Kong's constitutional crisis. Hastings International and Comparative Law Review, 26(2), 265-288.

Fong, E. \& Shen, J. (2011). Explaining ethnic enclave, ethnic entrepreneurial and employment niches: A case study of Chinese in Canadian immigrant gateway cities. Urban Studies, 48(8), 1605-1633.

Fong, T. P. (1994). The first suburban Chinatown: The remaking of Monterey Park, California. Philadelphia, PA: Temple University Press.

Food and Health Bureau, Hong Kong (2013, February 20). Replies to LegCo questions. Retrieved 31 May, 2017 from http://www.fhb.gov.hk/en/legco/replies/2013/lq130220_q01.htm

Gammeltoft-Hansen, T. \& Sørensen, N. N. (Eds.) (2013). The migration industry and the commercialization of international migration. London: Routledge.

Hiller, H. H. \& Franz, T. M. (2004). New ties, old ties and lost ties: The use of the Internet in diaspora. New Media \& Society, 6(6), 731-752.

Johnston, R., Trlin, A., Henderson, A., \& North, N. (2006). Sustaining and creating migration chains among skilled immigrant groups: Chinese, Indians and South Africans in New Zealand. Journal of Ethnic and Migration Studies, 32(7), 1227-1250. 
Kan, S. A. \& Morrison, W. M. (2013). U.S.-Taiwan relationship: Overview of policy issues. Current Politics and Economics of Northern and Western Asia, 22(1), 1-59.

Kessler, G. (2015, August 25). 'Birth tourists' and 'anchor babies': What Trump and Bush got right. The Washington Post. Retrieved 31 May, 2017 from https:/www.washingtonpost.com/news/fact-checker/wp/2015/08/25/birth-touristsand-anchor-babies-what-trump-and-bush-got-right/?utm_term $=.4 \mathrm{fa} 095793308$

Kopetman, R., Puente, K., \& Schwebke, S. (2015, May 18). Irvine attorney in birth tourism case arrested, accused of accepting money to help material witness get back to China. The Orange County Register. Retrieved 31 May, 2017 from http://www.ocregister.com/articles/liang-662190-witness-federal.html

$\mathrm{Ku}$, A. S. (2001). Hegemonic construction, negotiation and displacement: The struggle over right of abode in Hong Kong. International Journal of Cultural Studies, 4(3), 259278.

Lind, D. (2015, October 25). Why a Taiwanese woman gave birth on a plane - only to be separated from her child. Vox. Retrieved 31 May, 2017 from http://www.vox.com/2015/10/25/9604468/baby-plane-taiwanese

Lindquist, J., Xiang, B., \& Yeoh, B. S. A. (2012). Opening the black box of migration: Brokers, the organization of transnational mobility, and the changing political economy in Asia. Pacific Affairs, 85(1), 7-19.

Luibhéid, E. (2013). Pregnant on arrival: Making the illegal immigrant. Minneapolis, MN: University of Minnesota Press.

Mains, S. P., Gilmartin, M., Cullen, D., Mohammed, R., Tolia-Kelly, D. P., Raghuram, P., \& Winders, J. (2013). Postcolonial migrations. Social \& Cultural Geography, 14(2), $131-144$ 
Mau, S. (2010). Mobility citizenship, inequality, and the liberal state. International Political Sociology, 4(4), 339-361.

McKeown, A. (2012). How the box became black: Brokers and the creation of the free migrant. Pacific Affairs, 85(1), 21-45.

Meacham, C. (2016, May 2). 'Anchor babies' and birth tourists: Birthright citizenship and the racialized politics of belonging. Journal of Social and Cultural Analysis (blog post). Retrieved 31 May, 2017 from https://wp.nyu.edu/as-journalofsca/2016/05/02/anchorbabies-and-birth-tourists-birthright-citizenship-and-the-racialized-politics-ofbelonging/

Mikhael, M., Cleary, J. P., Dhar, V., Chen, Y., Nguyen, D. V., \& Chang, A. C. (2016). Birth tourism and neonatal intensive care: A children's hospital experience. American Journal of Perinatology, 33(14), 1415-1419.

people (2010, March 31). 香江客语 : 赴港生子, 无法预知的十年 (Reports from Hong Kong: [Chinese] birth tourism to Hong Kong, and the unpredictable ten years that followed). Retrieved 31 May, 2017 from http://hm.people.com.cn/GB/42490/11262784.html people (2013, September 26). 月子中心游走灰色地带 (Postpartum care centers operate in the grey area). Retrieved 31 May, 2017 from http://paper.people.com.cn/gjjrb/html/2013-09/26/content_1303397.htm people (2014,October 14). “赴美生子”人數 10 年翻百倍 产業鏈能養活上萬人 ([Chinese] birth tourism to US, a hundred-fold increase in yen years; industrial chain now supports more than ten-thousand people). Retrieved 31 May, 2017 from http://finance.people.com.cn/money/BIG5/n/2014/1014/c218900-25827629.html 
People's Daily (2001, July 21). HK government respects court's right of abode ruling. Retrieved 31 May, 2017 from http://en.people.cn/200107/21/eng20010721_75525.html

Pieke, F. N. (2007). Community and identity in the new Chinese migration order. Population, Space and Place, 13(2), 81-94.

Pieke, F. N. \& Mallee, H. (Eds.) (1999). International and international migration: Chinese perspectives. New York: Routledge.

qq.com (2015). Born in America. Retrieved 31 May, 2017 from http://news.qq.com/zt2015/borninUSA/

Rowen, I. (2016). The geopolitics of tourism: Mobilities, territory and protest in China, Taiwan, and Hong Kong. Annals of the American Association of Geographers, $106(2), 385-393$.

Roy, D. (2003). Taiwan: A political history. Ithaca, NY: Cornell University Press.

Shih, S.-M. (2007). Visuality and identity: Sinophone articulations across the Pacific. Berkeley, CA: University of California Press.

Shyong, F. (2016, December 30). Why birth tourism from China persists even as U.S. officials crack down. Los Angeles Times. Retrieved 31 May, 2017 from http://www.latimes.com/local/lanow/la-me-ln-birth-tourism-persists-20161220story.html

sina (2010, December 15). 本地中介形成赴美生子产业链 广州有妈妈网上组图生美宝 (Local intermediaries forming [Chinese] birth tourism industrial chain to the US; Guangzhou mothers forming tour groups for deliveries in the US). Retrieved 31 May, 2017 from http://finance.sina.com.cn/roll/20101215/00259107075.shtml

Siskin, A. (2011, January 4). Visa Waiver Program. Washington, DC: Congressional Research Service. 
So, A. Y. (2003). Cross-border families in Hong Kong: The role of social class and politics. Critical Asian Studies, 35(4), 515-534.

Trémon, A.-C. (2017). Flexible kinship: Shaping transnational families among the Chinese in Tahiti. Journal of the Royal Anthropological Institute, 23(1), 42-60.

Tsang, E. (2016, April 24). Mainland women gatecrashing Hong Kong's maternity wards, 3 years after CY Leung's 'zero-quota' policy. South China Morning Post. Retrieved 31 May, 2017 from http://www.scmp.com/news/hong-kong/healthenvironment/article/1938268/mainland-women-gatecrashing-hong-kongs-maternity

Vilhelmson, B. \& Thulin, E. (2013). Does the Internet encourage people to move? Investigating Swedish young adults' internal migration experiences and plans. Geoforum, 47, 209-216.

Wang, S. H. (2017). Fetal citizens? Birthright citizenship, reproductive futurism, and the 'panic' over Chinese birth tourism in southern California. Environment and Planning D: Society and Space, 35(2), 263-280.

Waters, J. (2003). Flexible citizens? Transnationalism and citizenship amongst economic immigrants in Vancouver. Canadian Geographer, 47(3), 219-234.

Waters, J. L. (2009). Immigration, transnationalism and 'flexible citizenship' in Canada: An examination of Ong's thesis ten years on. Tijdschrift voor economische en sociale geografie, 100(5), 635-645.

Wong, J. (2014, May 20). Canada's birthright citizenship policy makes us a nation of suckers. Toronto Life. Retrieved 31 May, 2017 from http://www.torontolife.com/informer/columns/2014/05/20/jan-wong-canadabirthright-citizenship-nation-of-suckers/

Wu, J.-Y. (2016). The representation of outbound Chinese tourists in the American news discourse. In F. K. C. Lee, P. C. W. Lee, K. S. M. Leung, \& K. C. Li (Eds.), 
Proceedings from the Second International Conference on Linguistics and Language Studies (pp. 270-283). Hong Kong: Chartered Institute of Linguists Hong Kong Society. Retrieved 31 May, 2017 from http://media.wix.com/ugd/2b7f97_77ecc5df67b740fb92ecf84f6d4b23a8.pdf

Xiang, B. (2003). Emigration from China: A sending country perspective. International Migration, 41(3), 21-48.

Xiang, B. (2012). Predatory princes and princely peddlers: The state and international labour migration intermediaries in China. Pacific Affairs, 85(1), 47-68.

Xiang, B. (2013). The intermediary trap: International labour recruitment, transnational governance and state-citizen relations in China. Asia Colloquia Papers, 3(1), 1-36. Toronto: York Centre for Asian Research.

Xiang, B. \& Lindquist, J. (2014). Migration infrastructure. International Migration Review, 48, S122-S148.

Yam, B. (2011). Cross-border childbirth between Mainland China and Hong Kong: Social pressures and policy outcomes. PORTAL Journal of Multidisciplinary International Studies, 8(2), 1-13.

Yam, S.-Y. S. (2016). Affective economies and alienizing discourse: Citizenship and maternity tourism in Hong Kong. Rhetoric Society Quarterly, 46(5), 410-433.

Yuen, C. Y. M. (2011). Cross-boundary students in Hong Kong schools: Education provisions and school experiences. In J. Phillion, M. T. Hue, \& Y. Wang (Eds.), Minority Students in East Asia: Government Policies, School Practices, and Teacher Responses (pp. 174-192). New York: Routledge.

\section{Notes}




\footnotetext{
${ }^{1}$ This material is based upon work supported by the National Science Foundation under Grants No. 1247399 and 1459137. Any opinions, findings, and conclusions or recommendations expressed in this material are those of the author and do not necessarily reflect the views of the National Science Foundation. The Maxwell School of Syracuse University provided additional support in the forms of an East Asia Summer Research Grant and a Hsu Scholarship.

${ }^{2}$ Interviews, March 2014 and June-July 2015.

${ }^{3}$ Although the PRC government began its emigration reform in 1978, state exit controls and dominant migration streams (e.g. student migrations) did not relax to the point of significantly increasing migrant numbers until the 1990s, with the PRC government adopting the 'Twelve-words Approach' as its official emigration policy: 'support study overseas, encourage returns, guarantee freedom of (international) movement' (see Pieke \&
} Mallee, 1999, 3; Xiang, 2003, 29).

${ }^{4}$ Following practical usage, Chinese terms from Taiwan and HK are written in traditional characters, while those from Mainland China are written in simplified characters.

${ }^{5}$ Interviews, November 2015 and Febraury-March 2016.

${ }^{6}$ Interviews, March 2014, June-July and October-November 2015.

${ }^{7}$ Interviews, November 2015.

${ }^{8}$ Interview, November 2015.

${ }^{9}$ Interview, November 2015.

${ }^{10}$ Interviews, November 2015.

${ }^{11}$ Interview, October 2015.

${ }^{12}$ Information session, November 2015.

${ }^{13}$ Interview, April 2016.

${ }^{14}$ Interview, May 2016. 